\title{
Chitosan film incorporated with Garcinia atroviridis for the packaging of Indian mackerel (Rastrelliger kanagurta)
}

\author{
Filme de quitosana incorporado com Garcinia atroviridis para embalagem \\ de cavala Indiana (Rastrelliger kanagurta)
}

\author{
Nurshahira Binti Khairul Zaman', Nyam Kar Lin¹, Pui Liew Phing ${ }^{1 *}$ \\ 'UCSI University, Faculty of Applied Sciences, Department of Food Science with Nutrition, Kuala Lumpur, Malaysia \\ *Corresponding author: puilp@ucsiuniversity.edu.my \\ Received in August 24, 2018 and approved in November 17, 2018
}

\begin{abstract}
Herbs and spices, having antimicrobial effect, can be incorporated into edible films, to extend product shelf life and the reduce the risk of microbial growth on food. The aim of this study is to develop chitosan film incorporated with Garcinia atroviridis, also known as 'asam gelugur', 'asam gelugo', or 'asam keping'. The film with different concentrations of Garcinia atroviridis ( 1 to $5 \% \mathrm{v} / \mathrm{v}$ ) with chitosan $(1.5 \% \mathrm{w} / \mathrm{v})$ were investigated for its physical, mechanical and antibacterial properties. With the increase of Garcinia atroviridis extract incorporated, water solubility of the films increases (from 21.17 to $53.61 \%$ ). Increase of Garcinia atroviridis incorporated into chitosan film also increase the total color difference. Film with higher concentration of Garcinia atroviridis extract produced thicker film compared to the film without extract (from 0.048 to $0.143 \mathrm{~mm}$ ). The film with $5 \%(\mathrm{v} / \mathrm{v}$ ) Garcinia atroviridis possessed low tensile strength (3.28 MPa) and elongation at break (13.90\%). Young's modulus was decreased in value (from 0.72 to $0.24 \mathrm{MPa}$ ) as the higher concentration of Garcinia atroviridis extract was added. High Garcinia atroviridis extract ( $5 \% \mathrm{v} / \mathrm{v})$ in the chitosan films demonstrated greater inhibitory activity against the bacteria strains (Pseudomonas aeruginosa, Bacillus subtilis and Staphylococcus aureus). With the edible film of $5 \%(\mathrm{v} / \mathrm{v})$ Garcinia atroviridis applied, the Indian mackerel was found to have a longer shelf life (3.5 days) as compared to the control ( 2.5 days).
\end{abstract}

Index terms: Herbs; edible film; storage.

\begin{abstract}
RESUMO
Ervas e especiarias, tendo efeito antimicrobiano, podem ser incorporadas em filmes comestíveis, para prolongar a vida de prateleira do produto e reduzir o risco de crescimento microbiano nos alimentos. Este estudo tem como objetivo desenvolver um filme de quitosana incorporado com Garcinia atroviridis, também conhecido como "asam gelugur", "asam gelugo", ou "asam keping". O filme com diferentes concentrações de Garcinia atroviridis (1-5\% v/v) com quitosana (1.5\% w/v) foi investigado por suas propriedades físicas e mecânicas. Com o aumento do extrato de Garcinia atroviridis incorporado, a solubilidade em água dos filmes aumenta (de 21.17 para 53.61\%). 0 aumento do Garcinia atroviridis incorporado ao filme de quitosana também aumenta a diferença total de cor. Filme com maior concentração de extrato de Garcinia atroviridis produziu filme mais espesso comparado ao filme sem extrato (de 0.048 a $0.143 \mathrm{~mm}$ ). 0 filme com $5 \%$ (v/v) de Garcinia atroviridis apresentou baixa resistência à tração (3.28 MPa) e alongamento (13.90\%). O módulo de Young foi diminuído em valor (de 0.72 a $0.24 \mathrm{MPa}$ ) à medida que a maior concentração de extrato de Garcinia atroviridis foi adicionada. O extrato de Garcinia atroviridis ( $5 \% \mathrm{v} / \mathrm{v}$ ) nos filmes de quitosana demonstrou maior atividade inibitória contra bactérias (Pseudomonas aeruginosa, Bacillus subtilis e Staphylococcus aureus). Com a película comestível de 5\% (v/v) de Garcinia atroviridis aplicada, a cavala indiana apresentou uma vida útil mais longa (3,5 dias) em comparação com o controle (2,5 dias).
\end{abstract}

Termos para indexação: Ervas; película comestível; armazenamento.

\section{INTRODUCTION}

Food packaging enable food to be safely distributed over long distance, maintaining its nutritional values and taste prior to consumption (Trinetta, 2016). It functions to protect the food from microbial growth (Coles; McDowell; Kirwan, 2009). Edible film can be made from proteins, lipids, resins, polysaccharides with or without the addition of other components (e.g. plasticizers, and surfactants)
(Cerqueira et al., 2011). Polysaccharides for films and coating is derived from starch and its derivatives, cellulose and its derivatives, alginates, carrageenan, various plant, microbial gums, chitosan and pectinates (Lin; Zhao, 2007).

Chitosan is commonly used as edible film due to its biocompatibility, biodegradability, non-toxicity and presenting functional properties as bacteriostatic and fungistatic (Hosseini et al., 2013). It has physical properties that is tougher, long lasting, flexibles and stiff (Jeon; Kamil; 
Shaihidi, 2002). Besides that, the addition of different herbs and spices into the edible film such as green tea, oregano and thyme, found to enhance the properties of the edible films (Seydim; Sarikus, 2006; Siripatrawan, Harte, 2010).

Garcinia atroviridis, also known as 'asam keping' or 'asam gelugor' is bright orange yellow and ripe, and commonly sliced, dried and commonly used in preparing dishes to season the curries, sour relish and for fish dressing as well (Mackeen et al., 2000; Phongpaichit et al., 2006). Extracts of Garcinia atroviridis possessed strong antibacterial activity against Bacillus subtilis B28 (mutant), B. subtilis B29 (wild type), methicillinresistant $S$. aureus, E. coli. While its root extracts showed strongest inhibition against Pseudomonas aeruginosa. Besides that, Garcinia atroviridis has antioxidant and antitumor promoting activities (Mackeen et al., 2000; Negi; Jayaprakasha; Jena, 2008).

Films and coatings can be applied onto the meat products such as chicken, beef and fish (Muppalla et al., 2014; Salgado et al., 2013; Chandra et al., 2016; Emiroğlu et al., 2010). Edible films functioned as a barrier to gases, moisture and solute thereby minimizing product quality deterioration (Toldra et al., 2014). Chitosan-based film has been applied onto rainbow trout and Alaska pollock and chicken fillet and the results reported that the film could retained and extended the shelf life of the food sample (Alemán et al., 2016; Ojagh et al., 2010; Khanjari; Karabagais; Kontominas, 2013). Remya et al. (2016) also reported that ginger essential oils incorporated chitosan film help in extend the shelflife of barracuda fish.

Indian mackerel is a type of fish that is commonly found in the coast area of Indian Ocean. In Malaysia, it is known the community as "Kembong" (Abdussamad et al., 2010). It is often available in the markets and cooked in many local dishes. Indian mackerel has blue-green color on its back, with flanks silver with golden tint. In addition, it has dark muscles that is associated with high content of lipid and myoglobin (Chaijan et al., 2004). The size of the Indian mackerel can be around $187 \mathrm{~mm}$ at 6.6 months and up to $217 \mathrm{~mm}$ length at 8.6 months (Abdussamad et al., 2010). Fish spoilage is resulted from microbial growth, are commonly caused by bacteria such as Pseudomonas, Alcaligenes, Virbrio, Serratia, Listeria, and Micrococcus (Ghaly et al., 2010; Lund; Baird-Parker; Gould, 2000; Abdollahzadeh et al., 2016).

Thus far, study edible film incorporated with Garcinia atroviridis applied on Indian mackerel has not been reported. This study focusses on the development of chitosan film incorporated with Garcinia atroviridis, in which the film produced is tested on its physica and mechanical characteristic. The antimicrobial properties and its application on Indian mackerel for storage test were also conducted.

\section{MATERIAL AND METHODS}

\section{Preparation and extraction of Garcinia atroviridis}

Garcinia atroviridis was purchased from the local market at Sungai Besi, Malaysia. It was cut and dried overnight at $60{ }^{\circ} \mathrm{C}$ before grinded using grinder (Sharp, EM-11, Malaysia). Grinded Garcinia atroviridis $(80 \mathrm{~g})$ was added into $800 \mathrm{~mL}$ ethanol (John Kollin Corporation, UK) and stirred overnight before filtration process. The filtrate was then subjected to rotary evaporator (Büchi, Switzerland) at $60^{\circ} \mathrm{C}$ (Mackeen et al., 2000).

\section{Preparation and production of film}

Chitosan solution $(1.5 \% \mathrm{w} / \mathrm{v})$ was prepared and acetic acid $(1 \% \mathrm{v} / \mathrm{v})$ was added into the solution and stirred for 24 hours before filtration. Different concentration of Garcinia atroviridis extract (1 to 5\% v/v) was added into the chitosan filtrate with $0.5 \%(\mathrm{v} / \mathrm{v})$ glycerol (Thermo Fisher, Malaysia) and $0.01 \%$ (v/v) Tween-80 (Thermo Fisher, Malaysia) before homogenized at 9,000 rpm for 4 minutes using homogenizer (Daihan Scientific, Korea). The solution $(25 \mathrm{~mL})$ was poured into the petri dish $(90 \mathrm{~mm} \times 15 \mathrm{~mm})$ for film casting for 24 hours at $40{ }^{\circ} \mathrm{C}$. Dried films were peeled manually using forceps (Ojagh et al., 2010).

\section{Analysis of film}

\section{Water solubility}

The water solubility test was conducted according to Mehdizadeh et al. (2012) with slight modification. The film was cut into $2 \mathrm{~cm} \times 2 \mathrm{~cm}$ and dried for 24 hours at $60{ }^{\circ} \mathrm{C}$. The dried film was placed into the boiling tube with $20 \mathrm{~mL}$ distilled water and covered for 3 hours before filtration. The second drying process also took place for 24 hours at the temperature of $60^{\circ} \mathrm{C}$ in the oven. After drying process, the film was collected and weighed. The water solubility of the film was calculated using the formula in Equation 1.

Water solubility $\%=\frac{\text { Initial dry weight }- \text { Final dry weight }}{\text { Initial dry weight }} \times 100$ 


\section{Color}

Color of the film was determined using colorimeter (ColorFlex Ez, Hunter lab, US) (Indrawati et al., 2015). The film color was expressed as L* (lightness-darkness), $\mathrm{a}^{*}$ (red-green) and $\mathrm{b}^{*}$ (yellow-blue) values. Total color differences $(\Delta \mathrm{E})$ for the films was calculated according to the Equation 2.

$$
\Delta E=\sqrt{\left(L-L^{*}\right)^{2}+\left(a-a^{*}\right)^{2}+\left(b-b^{*}\right)^{2}}
$$

Where $\mathrm{L}$, $\mathrm{a}$, and $\mathrm{b}$ were referring to the color perimeters of the film without extract and $L^{*}, a^{*}$ and $b^{*}$ were the values for the chitosan incorporated with Garcinia atroviridis.

\section{Thickness and mechanical properties}

The thickness of the film was measured using a manual micrometer (JY, China) according to method of Akhtar et al. (2010), by determining thickness in 5 different locations of the film.

Tensile strength, elongation at break and Young's modulus were determined according to Karki et al. (2016), in accordance to ASTM (2001) with slight modifications. Texture analyzer (Lloyd Instrument, UK) was pre-set for speed, gauge length, thickness, width, units (for tensile strength and elongation at break) before putting sample at the grip. The speed was set to $20 \mathrm{~mm} / \mathrm{min}$. The films were cut into $20 \times 70 \mathrm{~mm}$ rectangular strip and held parallel by the grip with a separation of $30 \mathrm{~mm}$. Tensile strength $(\mathrm{MPa})$ and elongation at break (\%) results were taken directly from the texture analyzer indicated by peak load $(\mathrm{N})$ and peak extension (\%) respectively. On the other hand, Young's modulus is calculated as the inclination of the initial linear portion of the stress versus strain curve, where the stress is force applied (F)/ cross sectional area (A) and strain is length of extension of film (e)/ original length of film (lo).

\section{Antimicrobial properties}

The antimicrobial properties of films were determined according to the Emiroğlu et al. (2010) with slight modification. Pseudomonas aeruginosa, Bacillus subtilis and Staphylococcus aureus were separately cultured in $10 \mathrm{~mL}$ of nutrient broths. Both Pseudomonas aeruginosa and Staphylococcus aureus were incubated for 24 hours at the temperature of $37^{\circ} \mathrm{C}$ while Bacillus subtilis was incubated for 24 hours at $30^{\circ} \mathrm{C}$. A bacterial suspension $(100 \mu \mathrm{L})$ was inoculated on Mueller-Hilton Agar (MHA, Thermo Fisher, Malaysia) and swabbed evenly using glass hockey stick under aseptic conditions.
After that, the edible film was cut into disc shape $(6 \mathrm{~mm})$ and placed onto MHA plate. The disc was placed and pressed gently using the sterile forceps. Streptomycin (10 mg/mL, Oxoid UK) was used as positive control for Pseudomonas aeruginosa and Penicillin $(10 \mathrm{mg} / \mathrm{mL}$, Oxoid UK) for Staphylococcus aureus and Bacillus subtilis as positive control. Negative control was prepared by impregnating $20 \mu \mathrm{L} 98 \%$ ethanol into $6 \mathrm{~mm}$ sterile paper disc (Whatman filter paper No. 3).

\section{Storage test of Indian mackerel}

Indian mackerel was washed with water to remove dirt and debris. Parts of Indian mackerel such as internal organs were removed from the Indian mackerel using sharp knife, before rinse using water. Deboning process was done by slicing horizontally through the Indian mackerel using sharp knife on the both side of the fish. After that, the Indian mackerel was cut into $2 \times 2 \mathrm{~cm}$. The chitosan incorporated with Garcinia atroviridis film was used to wrap the fish slices. The Indian mackerel without the film that served as control. All the Indian mackerel were placed at $4{ }^{\circ} \mathrm{C}$ (Heydari; Bavandi; Javadian, 2015).

Prior to analysis, the Indian mackerel with film was peeled before placed into the sterile stomacher bag. Sterile peptone water $(100 \mathrm{~mL})$ was added into the stomacher bag prior to homogenization process. The homogenization process was done in stomacher (Bagmixer 400, Window door, LGC Scientific, Malaysia) for 2 minutes. The analysis for Indian mackerel without film and chitosan with 5\% (v/v) Garcinia atroviridis film was conducted at each day for 6 days of storage. $\mathrm{pH}$ of each Indian mackerel with and without film wrapped were determined.

Total colony count was determined according to Salgado et al. (2013) with slight modifications. Homogenized Indian mackerel mixture went serial dilution for both chitosan with 5\% (v/v) Garcinia atroviridis film and control (without film). Homogenized mixture $(1 \mathrm{~mL})$ was added into $9 \mathrm{~mL}$ sterile peptone water (Synertec Enterprise, Malaysia) in test tube and shake gently to homogenize the solution. The serial dilutions were done from $10^{-1}$ up until $10^{-6}$ with peptone water and inoculated onto plate count agar (Chemolab, Malaysia). All the plates were incubated 24 hours at the temperature of $30^{\circ} \mathrm{C}$ in incubator (S1500, Stuart, UK). The number of colonies count after 24 hours were converted into logarithms for number of colony forming units (cfu/mL).

\section{Statistical analysis}

Data were represented as a mean value \pm standard deviation $(\mathrm{n}=3)$ and analysed using analysis of variance 
(one-way ANOVA) (Minitab 17 software), with Tukey's test at a significance level of $p<0.05$.

\section{RESULTS AND DISCUSSION}

\section{Effect of Garcinia atroviridis extract on the properties of chitosan film}

\section{Water solubility}

Film solubility in water was defined as the content of dry matter solubilized after $24 \mathrm{~h}$ of immersion (Belibi et al., 2014). Based on Table 1, the water solubility ranged from $21.17 \%$ to $53.61 \%$. Chitosan film shows $21.17 \%$ of water solubility and the water solubility increased to $25.12 \%$ when $1 \%(\mathrm{v} / \mathrm{v})$ of Garcinia atroviridis extract added into chitosan film.

Table 1: Water solubility (\%) on different concentration of Garcinia atroviridis extracts incorporated into chitosan film (1.5\%w/v).

\begin{tabular}{cc}
\hline $\begin{array}{c}\text { Concentration of Garcinia } \\
\text { atroviridis (\%v/v) }\end{array}$ & Water solubility (\%) \\
\hline 0 & $21.17 \pm 3.309^{\mathrm{a}}$ \\
1 & $25.12 \pm 2.789^{\mathrm{ab}}$ \\
2 & $35.82 \pm 6.468^{\mathrm{b}}$ \\
3 & $48.21 \pm 2.004^{\mathrm{c}}$ \\
4 & $48.56 \pm 6.666^{\mathrm{c}}$ \\
5 & $53.61 \pm 4.354^{\mathrm{d}}$ \\
\hline
\end{tabular}

Values were expressed as triplicate in mean \pm standard deviation. ${ }^{\text {a-d }}$ different superscripts within the same column indicate significant differences between formulations $(p<0.05)$.

According to Mehdizadeh et al. (2012), higher solubility of edible film is favorable during cooking but not during storage. Low water solubility is required to control the contamination occurred during storage. However, in this study showed incorporation of Garcinia atroviridis extract increased the hydrophilic properties. These finding is in agreement with Jutaporn, Suphitchaya and Thawien (2011) whereby the hydroxylpropyl methyl cellulose (HPMC) film incorporated with Phayom wood extract (Shorea tolura) increased its film solubility from $25 \%$ (control film) to $40 \%$ ( $1500 \mathrm{mg} / \mathrm{L}$ extract $)$. The extract might contribute to the intermolecular interaction in HPMC film matrix therefore enhanced the moisture passing through films. Similar result was obtained when propolis extract added into gelatin film (Bodini et al., 2013). The film solubility had increased from $8.1 \%$ to $18.6 \%$. Garcinia atroviridis extracts elevated the water solubility of chitosan film might due to the water-soluble compound (hydroxycitric acid) found in Garcinia atroviridis (Roongpisuthipong; Kantawan; Roongpisuthipong, 2007).

\section{Effect on color}

Color is one of the sensory attributes that determined consumer acceptance. It could perceive quality and acceptability and serve as signal of quality or deterioration in foods (Macfie, 2012). Based on the result in Table 2, with the increase of Garcinia atroviridis.

For L* parameter, the $1 \%(\mathrm{v} / \mathrm{v})$ Garcinia atroviridis showed the highest value indicated lighter color of film. Mehdizadeh et al. (2012) reported that the incorporation of thyme essential oil into starch chitosan films showed decreasing in $\mathrm{L}^{*}$ value indicated that film without essential oil is lighter. Besides that, another study by Chana-Thaworn, Chanthachum and Wittaya (2011) also in the same agreement that addition of Kiam wood affected the $\mathrm{L}^{*}$ value continued to reduce with increase of concentration. Generally, all chitosan films incorporated with Garcinia atroviridis extract were in yellow-brownish color. Chitosan film appeared to be clear transparent film with slight yellowish color. Color appeared in chitosan film with Garcinia atroviridis extract is due to the pigments in Garcinia atroviridis called xanthonoids (Mackeen et al., 2000).

\section{Thickness and mechanical properties}

The thickness of the films was measured manually using micrometer and the results were reported as shown in Table 3. Based on the result in Table 3, chitosan film showed $0.048 \mathrm{~mm}$ thickness and it increased to $0.068 \mathrm{~mm}$ as $1 \%(\mathrm{v} / \mathrm{v})$ of the Garcinia atroviridis extract incorporated into the chitosan film. Thus, the film thickness increased as higher concentration of Garcinia atroviridis extract added. Thicker film indicated that Garcinia atroviridis extracts had filled the chitosan matrix causing an increase of the film thickness. Similar result obtained for the increasing chitosan concentration incorporated.

Similar study was reported by Mulla et al. (2017) showed the thickness and weight of LLDPE films with clove essential oil was greater compare to the film without the essential oil. Different in thickness in films also could due by the molecular weight of the film solution even though amount of the solution before the film casting is constant for every film. Different concentration of extract could contribute different weight therefore increase the thickness of films (Siripatrawan; Harte, 2010). 
Table 2: The parameter of color indifferent concentration of Garcinia atroviridis extract incorporated into chitosan films.

\begin{tabular}{ccccc}
\hline $\begin{array}{c}\text { Concentration of Garcinia } \\
\text { atroviridis }(\% \mathrm{v} / \mathrm{v})\end{array}$ & $\mathrm{L}^{*}$ & $\mathrm{a}^{*}$ & $\mathrm{~b}^{*}$ & $\Delta \mathrm{E}$ \\
\hline 0 & $29.62 \pm 0.01^{\mathrm{f}}$ & $-1.18 \pm 0.03^{\mathrm{a}}$ & $4.88 \pm 0.02^{\mathrm{a}}$ & 0.00 \\
1 & $29.07 \pm 0.07^{\mathrm{e}}$ & $2.75 \pm 0.03^{\mathrm{b}}$ & $6.38 \pm 0.02^{\mathrm{b}}$ & 4.24 \\
2 & $26.74 \pm 0.01^{\mathrm{d}}$ & $2.81 \pm 0.00^{\mathrm{b}}$ & $6.83 \pm 0.01^{\mathrm{c}}$ & 5.29 \\
3 & $24.01 \pm 0.01^{\mathrm{c}}$ & $3.02 \pm 0.03^{\mathrm{c}}$ & $8.13 \pm 0.07^{\mathrm{d}}$ & 7.72 \\
4 & $21.89 \pm 0.02^{\mathrm{b}}$ & $4.33 \pm 0.01^{\mathrm{d}}$ & $9.63 \pm 0.06^{\mathrm{e}}$ & 10.61 \\
5 & $18.22 \pm 0.01^{\mathrm{a}}$ & $7.29 \pm 0.02^{\mathrm{e}}$ & $11.07 \pm 0.02^{\mathrm{f}}$ & 15.49 \\
\hline
\end{tabular}

Values were expressed as triplicate in mean \pm standard deviation. ${ }^{\text {aff }}$ different superscripts within the same column indicate significant differences between formulations $(p<0.05)$.

Table 3: The thickness and mechanical properties on different concentration of Garcinia atroviridis extract incorporated into chitosan film.

\begin{tabular}{ccccc}
\hline $\begin{array}{c}\text { Concentration of Garcinia } \\
\text { atroviridis }(\% \mathrm{v} / \mathrm{v})\end{array}$ & $\begin{array}{c}\text { Thickness } \\
(\mathrm{mm})\end{array}$ & $\begin{array}{c}\text { Tensile strength } \\
(\mathrm{MPa})\end{array}$ & $\begin{array}{c}\text { Elongation at break } \\
(\%)\end{array}$ & $\begin{array}{c}\text { Young's Modulus } \\
(\mathrm{MPa})\end{array}$ \\
\hline 0 & $0.048 \pm 0.003^{\mathrm{a}}$ & $13.37 \pm 1.22^{\mathrm{c}}$ & $18.47 \pm 1.24^{\mathrm{b}}$ & $0.72 \pm 0.02^{\mathrm{c}}$ \\
1 & $0.068 \pm 0.007^{\mathrm{b}}$ & $7.76 \pm 0.79^{\mathrm{b}}$ & $17.32 \pm 1.80^{\mathrm{ab}}$ & $0.45 \pm 0.02^{\mathrm{b}}$ \\
2 & $0.081 \pm 0.004^{\mathrm{c}}$ & $6.64 \pm 0.87^{\mathrm{b}}$ & $17.05 \pm 1.52^{\mathrm{ab}}$ & $0.40 \pm 0.09^{\mathrm{b}}$ \\
3 & $0.091 \pm 0.003^{\mathrm{c}}$ & $3.92 \pm 0.47^{\mathrm{a}}$ & $15.52 \pm 1.41^{\mathrm{ab}}$ & $0.25 \pm 0.01^{\mathrm{ab}}$ \\
4 & $0.096 \pm 0.003^{\mathrm{c}}$ & $3.45 \pm 0.53^{\mathrm{a}}$ & $13.00 \pm 3.32^{\mathrm{a}}$ & $0.28 \pm 0.12^{\mathrm{ab}}$ \\
5 & $0.143 \pm 0.012^{\mathrm{d}}$ & $3.28 \pm 0.75^{\mathrm{a}}$ & $13.90 \pm 2.62^{\mathrm{a}}$ & $0.24 \pm 0.05^{\mathrm{a}}$ \\
\hline
\end{tabular}

Values were expressed as triplicate in mean \pm standard deviation. ${ }^{\text {a-d }}$ different superscripts within the same column indicate significant differences between formulations $(p<0.05)$.

Mechanical properties of film could be tested by tensile strength test. Tensile strength is the capacity of material to withstand loads without fracture against the cross-sectional area of the material (Siripatrawan; Harte, 2010; Mulla et al., 2017). Based on the result in the Table 3, the tensile strength ranged from $3.28 \mathrm{MPa}$ to $13.37 \mathrm{MPa}$. Tensile strength for chitosan film was $13.37 \mathrm{MPa}$ and it reduced to $7.76 \mathrm{MPa}$ when $1 \%$ (v/v) of Garcinia atroviridis extracts was added into chitosan film. The tensile strength was continued to reduce as the Garcinia atroviridis extracts added. The tensile strength decreased as the concentration of Garcinia atroviridis increased. This showed that higher concentration of Garcinia atroviridis could cause the film to be easily break.

This result was supported by Hosseni et al. (2013), who found that the tensile strength values were weaker for films containing thyme and clove essential oils. The loss of tensile strength may be caused by the breakup of the film network with the addition of essential oil (Pranoto; Rakshit; Salokhe, 2005). Garcinia atroviridis extract was reported to contain xanthone and hydroquinone, and several potential antioxidants such as atroviridin, atrovirisidone and garcinol isolated through methanolic extraction (Permana et al., 2001).

Elongation at break is to measure of ductility, or ability of a material to deform plastically before fracturing. It is usually expressed as a percentage of the original gage length (Kaufman et al., 1997). Elongation is important as it measures how much bending and shaping as material can withstand without breaking. Based on the Table 3, the elongation at break ranged from $13.00 \%$ to $18.47 \%$. Chitosan film showed highest elongation at break value $(18.47 \%)$ and this property reduced to $17.32 \%$ as $1 \%$ of Garcinia atroviridis extract was added into chitosan film. The elongation at break value was continued to reduce as higher concentration of Garcinia atroviridis incorporated.

Lower elongation at break indicates the brittle materials and do not plastically deform. Study from Zailuddin and Husseinsyah (2016) demonstrated decreased in elongation at break of regenerated cellulose bio 
composite films at $2 \%$ and it attributed to the presence of oil palm empty fruit bunch which strain the slippage movement of regenerated cellulose chain during the deformation and resulting in lower elongation at break thus decreased the chain mobility of regenerated cellulose bio composite films. This indicated that the film formed was rigid than other percentage. Decreased in elongation at break of chitosan film when incorporated with Garcinia atroviridis extract indicated that film has low ductility.

Young's modulus is a measure of the ability of material to withstand changes in length when under lengthwise tension or compression. Based on the Table 3, the Young's modulus ranged from $0.24 \mathrm{MPa}$ to $0.72 \mathrm{MPa}$. Chitosan film showed the highest Young's modulus among the films with $0.72 \mathrm{MPa}$ and the value reduce to $0.45 \mathrm{MPa}$ as $1 \%(\mathrm{v} / \mathrm{v})$ of Garcinia atroviridis extract incorporated into chitosan film. Therefore, it was concluded that addition of Garcinia atroviridis extract showed the low value of Young's modulus indicated high stiffness in film. The decrease in mechanical strength may be attributed to the discontinuities in the polymer matrix introduced by the incorporation of Garcinia atroviridis extract and by changes in the polymer interaction when the components of Garcinia atroviridis are present, leading to a weaker mechanical response by the chitosan film (Sánchez-González et al., 2010).

\section{Antimicrobial properties}

The antimicrobial effect of Garcinia atroviridis is shown in the Table 4. The different concentrations of Garcinia atroviridis extracts were incorporated into chitosan films to test the antimicrobial properties of Garcinia atroviridis, against Pseudomonas aeruginosa, Bacillus subtilis and Staphylococcus aureus.

Based on the result in Table 4, chitosan with 3\% $(\mathrm{v} / \mathrm{v})$ Garcinia atroviridis showed the beginning of the inhibitory action occurred $(7.33 \mathrm{~mm})$ and increased as concentration of this extract increased. Chitosan with 5\% (v/v) Garcinia atroviridis film showed the highest inhibition zone $(10.33 \mathrm{~mm})$. Higher Garcinia atroviridis extract incorporated showed positive inhibitory action towards bacteria Pseudomonas aeruginosa. Similar studies reported by Emiroğlu et al. (2010) showed that high inhibition zone was detected when oregano and thyme essential oil (5\%) incorporated into whey protein film, with the inhibition zone of $39.5 \mathrm{~mm}$ and $42.00 \mathrm{~mm}$, respectively.

The chitosan with $3 \%(\mathrm{v} / \mathrm{v})$ Garcinia atroviridis film potrayed inhibitory action against Bacillus subtilis $(10.00 \mathrm{~mm})$ and inhibition zone increased as the concentration of this extract increase (Table 4). The highest inhibition zone showed by chitosan with $5 \%(\mathrm{v} / \mathrm{v})$ Garcinia atroviridis film at $13.33 \mathrm{~mm}$. On the other hand, the inhibition zone in Staphylococcus aureus ranged from $6 \mathrm{~mm}$ to $12.67 \mathrm{~mm}$ (Table 4). Similar finding reported by Seydim and Sarikus (2006) whereby the addition of oregano essential oil at $2 \%$ (v/v) was found to inhibit the Staphylococcus aureus with inhibition zone at $5.8 \mathrm{~mm}$. Another study by Shaaban et al. (2014) showed that methyl cellulose film incorporated with Marjoram essential oil gave out the result of $40 \mathrm{~mm}$ inhibition zone against Staphylococcus aureus.

There was no inhibition zone detected for chitosan film and chitosan with $1 \%$ (v/v) Garcinia atroviridis extract film. However, the film showed inhibitory effect at $2 \%(\mathrm{v} / \mathrm{v})$ addition of Garcinia atroviridis extract $(8 \mathrm{~mm})$, only for the Staphylococcus aureus. The inhibition zone increases as higher concentration of Garcinia atroviridis extract incorporated into chitosan film, with highest inhibition zone of film against Staphylococcus aureus, of $12.67 \mathrm{~mm}$ at chitosan with 5\% (v/v) Garcinia atroviridis film. The Staphylococcus aureus did not show growth on top of the film.

Table 4: The antibacterial activity of Garcinia atroviridis extracts incorporated with chitosan film on main strains of bacteria found in Indian mackerel.

\begin{tabular}{cccc}
\hline \multirow{2}{*}{$\begin{array}{c}\text { Concentration of Garcinia } \\
\text { atroviridis (\%v/v) }\end{array}$} & \multicolumn{2}{c}{ Inhibition zone, mm including film (6 mm) } \\
\cline { 2 - 4 } & Pseudomonas aeruginosa & Bacillus subtilis & Staphylococcus aureus \\
\hline 0 & $6.00 \pm 0.00^{\mathrm{a}}$ & $6.00 \pm 0.00^{\mathrm{a}}$ & $6.00 \pm 0.00^{\mathrm{a}}$ \\
1 & $6.00 \pm 0.00^{\mathrm{a}}$ & $6.00 \pm 0.00^{\mathrm{a}}$ & $6.00 \pm 0.00^{\mathrm{a}}$ \\
2 & $6.00 \pm 0.00^{\mathrm{a}}$ & $6.00 \pm 0.00^{\mathrm{a}}$ & $8.00 \pm 0.00^{\mathrm{b}}$ \\
3 & $7.33 \pm 1.16^{\mathrm{ab}}$ & $10.00 \pm 1.00^{\mathrm{b}}$ & $10.67 \pm 1.16^{\mathrm{c}}$ \\
5 & $8.00 \pm 0.00^{\mathrm{b}}$ & $10.67 \pm 1.16^{\mathrm{b}}$ & $10.67 \pm 1.16^{\mathrm{c}}$ \\
5 & $10.33 \pm 0.56^{\mathrm{c}}$ & $13.33 \pm 0.58^{\mathrm{c}}$ & $12.67 \pm 0.28^{\mathrm{d}}$ \\
\hline
\end{tabular}

Values were expressed as triplicate in mean \pm standard deviation. ${ }^{\text {add }}$ different superscripts within the same column indicate significant differences between formulations $(p<0.05)$. 
Garcinia atroviridis extract was reported to have inhibitory effect against the Gram-positive bacteria strain like Staphylococcus aureus (Basri et al., 2005). Therefore, it explained greater inhibition zone observed at Gram-positive bacteria (Staphylococcus aureus and Bacillus subtilis.) compared to Gram-negative bacteria (Pseudomonas aeruginosa). The reason for higher sensitivity of Gram-positive bacteria compared to Gram-negative bacteria is due to their differences in cell membrane constituents and arrangement. For Grampositive bacteria, it consists of an outer peptidoglycan which is an ineffective permeability barrier (Negi; Jayaprakasha; Jena, 2008).

\section{Storage test of Indian mackerel}

$\mathrm{pH}$ of the Indian mackerel was measured during storage test at 0 to 6 days of storage using $\mathrm{pH}$ meter. The changes of $\mathrm{pH}$ recorded are shown in Table 5 for both control (no film) and chitosan with 5\% (v/v) Garcinia atroviridis film. With increase of storage time, the $\mathrm{pH}$ of both Indian mackerel with (chitosan with 5\% v/v Garcinia atroviridis) and without film (control) decreases, from 5.78 to 3.98 , and 8.19 to 6.26 , respectively. $\mathrm{pH}$ of 3.98 could be categorized under acidic condition. This situation could probably due to the hydroxycitric acid in Garcinia atroviridis that leached out to the Indian mackerel flesh resulted in low pH (Basri et al., 2005).

Table 5: The changes of $\mathrm{pH}$ throughout the storage period.

\begin{tabular}{ccc}
\hline $\begin{array}{c}\text { Storage } \\
\text { (day) }\end{array}$ & $\begin{array}{c}\text { Control } \\
\text { (no film) }\end{array}$ & $\begin{array}{c}\text { Chitosan and } 5 \%(\mathrm{v} / \mathrm{v}) \\
\text { Garcinia atroviridis }\end{array}$ \\
\hline 0 & $8.19 \pm 0.15^{\mathrm{Ac}}$ & $5.78 \pm 0.02^{\mathrm{Bd}}$ \\
1 & $7.89 \pm 0.04^{\mathrm{Abc}}$ & $5.72 \pm 0.04^{\mathrm{Bd}}$ \\
2 & $7.53 \pm 0.11^{\mathrm{Ab}}$ & $5.13 \pm 0.12^{\mathrm{Bc}}$ \\
3 & $6.41 \pm 0.08^{\mathrm{Aa}}$ & $4.22 \pm 0.09^{\mathrm{Bb}}$ \\
4 & $6.57 \pm 0.14^{\mathrm{Aa}}$ & $4.07 \pm 0.08^{\mathrm{Ba}}$ \\
5 & $6.45 \pm 0.35^{\mathrm{Aa}}$ & $4.11 \pm 0.07^{\mathrm{Bab}}$ \\
6 & $6.26 \pm 0.35^{\mathrm{Aa}}$ & $3.98 \pm 0.05^{\mathrm{Ba}}$ \\
\hline
\end{tabular}

Values were expressed as triplicate in mean \pm standard deviation. ${ }^{a-d}$ different superscripts within the same column indicate significant differences between formulations $(p<0.05)$. ${ }^{A-B}$ different superscript within the same row indicate significant difference between 2 different storage conditions in Pair-T test value $(p<0.05)$.

Fish with and without chitosan film with $5 \%(\mathrm{v} / \mathrm{v})$ Garcinia atroviridis showed increasing order as the day of storage increase (Figure 1). Maximum total colony count for control and chitosan with 5\% (v/v) Garcinia atroviridis film was $\log 8.8$ and 8.3, respectively. At day 0 to day 1 , no presence of colony was found. The total colony count increased on day 2 for both control and chitosan with $5 \%(\mathrm{v} / \mathrm{v})$ Garcinia atroviridis film. Nevertheless, total colony count for control was higher (log 4) compared to total colony count for chitosan with 5\% (v/v) Garcinia atroviridis film (log 2.9). This situation indicated that Garcinia atroviridis extract incorporated in chitosan film was capable to reduce the number of microbial growths on Indian mackerel thus extended the spoilage.

The total colony count for both control and chitosan with $5 \%(\mathrm{v} / \mathrm{v})$ Garcinia atroviridis film continued to increase at day 3 . For Indian mackerel without film, the total colony count was $\log 6.9$ which passed the total colony count for the safe consumption. The dotted line at $\log 6$ indicated the maximum limit of total colony count for the food to be safe for consumption (Tomac; Yeannes, 2012). While for Indian mackerel with chitosan and 5\% (v/v) Garcinia atroviridis film, it was still below the maximum total colony count and it assumed can be consumed whereby the total colony count was $\log 4.8$. A lower total colony count in Indian mackerel that is wrapped with Garcinia atroviridis film compared to control, was in agreement with the work of Salgado et al. (2013), where the sunflower protein film incorporated with clove essential oil applied onto Sardine fish patties was also found to have lower total colony count (log 6.61) compared to the control $(\log 7)$ at day 3 .

At day 4 of storage, sample without film increase exponentially in total colony count. This indicates that the spoilage bacteria grow rapidly on the Indian mackerel sample for control. While for Indian mackerel wrapped with chitosan with 5\% (v/v) Garcinia atroviridis film, the total colony count exceed log 6 . The total colony count for Indian mackerel wrapped with $5 \%$ (v/v) Garcinia atroviridis chitosan film at day 4 was $\log$ 6.9. Hence, it indicated that the Indian mackerel with film was started to grow spoilage bacteria that caused it unsafe for consumption. Therefore, control film could only can withstand about 2 and half day while being kept in $4{ }^{\circ} \mathrm{C}$. Comparing with chitosan with $5 \%(\mathrm{v} / \mathrm{v})$ Garcinia atroviridis film applied onto Indian mackerel, the shelf life was extended until 3 and half day of storage. Thus, it shows that addition of chitosan with 5\% (v/v) Garcinia atroviridis extract in film can be applied to extend the shelf life of the Indian mackerel at chill temperature. 


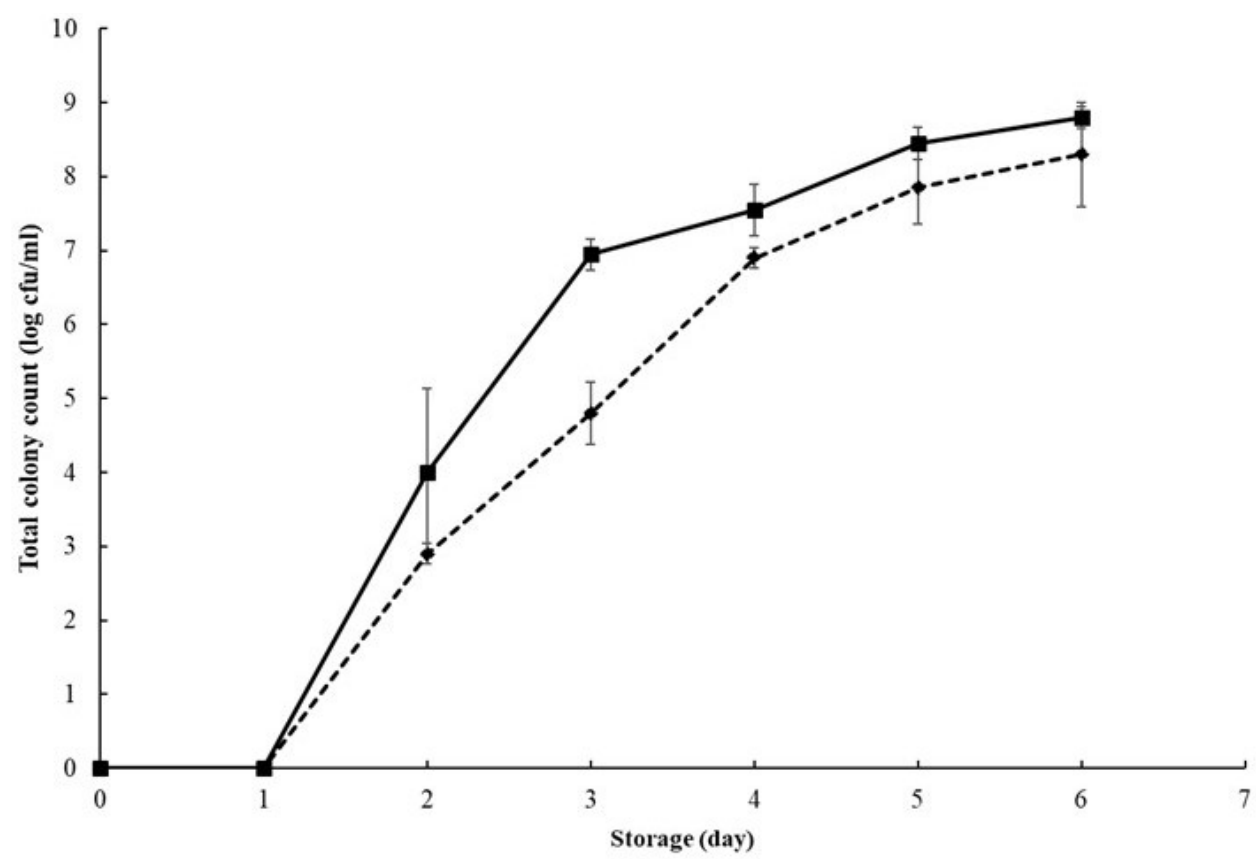

Figure 1: Total colony count in log (cfu/mL) during storage. (--) Indian mackerel without film, (-) Indian mackerel with chitosan film and 5\% (v/v) Garcinia atroviridis.

Reduction of total colony count in chitosan with $5 \%$ (v/v) Garcinia atroviridis film Indian mackerel were due to the antimicrobial properties of Garcinia atroviridis extract that well coated the Indian mackerel upon storage. Hence it could help in extended the consumption time for the f Indian mackerel compared to the control.

\section{CONCLUSIONS}

The objective of this study is to develop chitosan film incorporated with 'asam keping' for Indian mackerel, where the physical, mechanical, chemical, antimicrobial of the film were determined, and storage test was for 6 days. Higher concentration of Garcinia atroviridis incorporated into chitosan film resulted in high water solubility in film, with decrease in tensile strength, elongation at break and Young's modulus. Although higher concentration of Garcinia atroviridis incorporated in film increased inhibition zone against all bacteria (Pseudomonas aeruginosa, Bacillus subtilis, Staphylococcus aureus), the film with high concentration $(\geq 6 \%)$ Garcinia atroviridis were easily dispersed when contact with agar plate. Therefore, 5\% (v/v) Garcinia atroviridis was selected for further development with different chitosan concentration. The chitosan film with 5\% (v/v) Garcinia atroviridis was applied on the Indian mackerel for 6 days storage, where its shelf life was extended to 3.5 days, while the fish without film has a shorter shelf life of 2.5 days.

\section{ACKNOWLEDGMENTS}

The authors would like to acknowledge the financial support provided by UCSI University (PSIF-InFAS-056) under Pioneer Scientist Incentive Fund.

\section{REFERENCES}

ABdollahzadeh, E. et al. Prevalence and molecular characterization of Listeria spp. and Listeria monocytogenes isolated from fish, shrimp, and cooked ready-to-eat (RTE) aquatic products in Iran. LWT - Food Science and Technology, 73:205-211, 2016.

ABDUSSAMAD, E. et al. Fishery, biology and population characteristics of the Indian mackerel, Rastrelliger kanagurta (Cuvier) exploited along the Tuticorin coast. Indian Journal Fish, 57(1):17-21, 2010.

AKHTAR, M. et al. Control of salmon oil photo-oxidation during storage in HPMC packaging film: Influence of film colour. Food Chemistry, 120(2):395-401, 2010.

ALEMÁN, A. et al. Comparative study between film and coating packaging based on shrimp concentrate obtained from 
marine industrial waste for fish sausage preservation. Food Control, 70:325-332, 2016.

ASTM Standard D882. Standard test method for tensile properties of thin plastic sheeting. In: Annual Book of ASTM Standards. American Society for Testing and Materials, Philadelphia, PA, p.162-170, 2001.

BASRI, D. F. et al. Evaluation of antimicrobial activities of the crude extracts from Garcinia atroviridis and Solanum torvum. Malaysia Journal Science, 24(1):233-238, 2005.

BELIBI, P. et al. A comparative study of some properties of cassava and tree cassava starch films. Physics Procedia, 55:220-226, 2014.

BODINI, R. et al. Properties of gelatin-based films with added ethanol-propolis extract. Food Science and Technology, 51(1):104-110, 2013.

CERQUEIRA, M. et al. Galactomannans use in the development of edible films/coatings for food applications. Trends in Food Science and Technology, 22(12):662-671, 2011.

CHAIJIAN, M. et al. Characteristics and gel properties of muscles from sardine (Sardinella gibbosa) and mackerel (Rastrelliger kanagurta) caught in Thailand. Food Research International, 37(10):1021-1030, 2004.

CHANA-THAWORN, J.; CHANTHACHUM, S.; WITTAYA, T. Properties and antimicrobial activity of edible films incorporated with kiam wood (Cotyleobium lanceotatum) extract. LWT - Food Science and Technology, 44(1):284292, 2011.

CHANDRA, M. C. et al. Design and characterization of spice fused tamarind starch edible packaging films. LWT - Food Science and Technology, 68:642-652, 2016.

COLES, R.; MCDOWELL, D.; KIRWAN, M. Food Packaging Technology. 1st ed. Williston: Wiley, 76p, 2009.

EMIROĞLU, Z. et al. Antimicrobial activity of soy edible films incorporated with thyme and oregano essential oils on fresh ground beef patties. Meat Science, 86(2):283-288, 2010.

GHALY, A. et al. Fish spoilage mechanisms and preservation techniques: Review. American Journal of Applied Sciences, 7(7):859-877, 2010.

HEYDARI, R.; BAVANDI, S.; JAVADIAN, S. R. Effect of sodium alginate coating enriched with horsemint (Mentha longifolia) essential oil on the quality of bighead carp fillets during storage at $4^{\circ} \mathrm{C}$. Food Science and Nutrition, 3(3):188194, 2015.
HOSSEINI, S. et al. Preparation and functional properties of fish gelatin-chitosan blend edible films. Food Chemistry, 136(3-4):1490-1495, 2013.

INDRAWATI, R. et al. Encapsulation of brown seaweed pigment by freeze drying: Characterization and its stability during storage. Procedia Chemistry, 14:353360, 2015.

JEON, Y. I.; KAMIL, J. Y. V. A.; SHAIHIDI, F. Chitosan as an edible invisible film for quality preservation of herring and Atlantic cod. Journal of Agricultural and Food Chemistry, 20:5167-5178, 2002.

JUTAPORN, C.; SUPHITCHAYA, C.; THAWIEN, W. Antimicrobial activity and characteristics of edible films incorporated with Phayom wood (Shorea tolura) extract. International Food Research Journal, 18:39-54, 2011.

KARKI, S. et al. Thin films as an emerging platform for drug delivery. Asian Journal of Pharmaceutical Science, 11:559-574, 2016.

KAUFMAN, J. et al. ASM ready reference: Properties and units for engineering alloys. Materials Park, OH: ASM International, 73p, 1997.

KHANJARI, A.; KARABAGAIS, I.; KONTOMINAS, M. Combined effect of N, O-carboxymethyl chitosan and oregano essential oil to extend shelf life and control Listeria monocytogenes in raw chicken meat fillets. LWT - Food Science and Technology, 53(1):94-99, 2013.

LIN, D.; ZHAO, Y. Innovations in the development and application of edible coatings for fresh and minimally processed fruits and vegetables. Comprehensive Reviews in Food Science and Food Safety, 6(3):60-75, 2007.

LUND, B.; BAIRD-PARKER, T.; GOULD, G. The microbiological safety and quality of food. 1st ed. Gaithersburg, Md.: Aspen Publishers, 2000. 506p.

MACFIE, H. Food choice, acceptance and consumption. London: Springer, 2012. 12p.

MACKEEN, M. et al. Antimicrobial, antioxidant, antitumour promoting and cytotoxic activities of different plant part extracts of Garcinia atroviridis Griff. ex T. Anders. Journal of Ethnopharmacology, 72(3):395402, 2000.

MEHDIZADEH, T. et al. Antibacterial, antioxidant and optical properties of edible starch-chitosan composite film containing Thymus kotschyanus essential oil. Veterinary Research Forum, 3:167-173, 2012. 
MULLA, M. et al. Anti-microbial efficacy of clove essential oil infused into chemically modified LLDPE film for chicken meat packaging. Food Control, 73:663-671, 2017.

MUPPALLA, S. R. et al. Carboxymethyl cellulose-polyvinyl alcohol films with clove oil for active packaging of ground chicken meat. Food Packaging and Shelf Life, 2(2): 51 $58,2014$.

NEGI, P.; JAYAPRAKASHA, G.; JENA, B. Anti-bacterial activity of the extracts from the fruit rinds of Garcinia cowa and Garcinia pedunculata against food borne pathogens and spoilage bacteria. LWT - Food Science and Technology, 41(10):1857-1861, 2008.

OJAGH, S. et al. Effect of chitosan coatings enriched with cinnamon oil on the quality of refrigerated rainbow trout. Food Chemistry, 120(1):193-198, 2010.

PERMANA, D. Isolation and bioactivities of constitutents of the roots of Garcinia aroviridis. Journal of Natural Products, 64(7): 976-979, 2001.

PHONGPAICHIT, S. et al. Antimicrobial activity in cultures of endophytic fungi isolated from Garcinia species. FEMS Immunology and Medical Microbiology, 48(3):367-372, 2006.

PRANOTO, Y.; RAKSHIT, S. K.; SALOKHE, V. M. Enhancing antimicrobial activity of chitosan films by incorporating garlic oil, potassium sorbate and nisin. LWT-Food Science and Technology, 38(8):859-865, 2005.

REMYA, S. et al. Effect of chitosan based active packaging film on the keeping quality of chilled stored barracuda fish. Journal of Food Science and Technology, 53 (1):685-693, 2016.

ROONGPISUTHIPONG, C.; KANTAWAN, R. M.; ROONGPISUTHIPONG, C. Reduction of adipose tissues and body weight: Effect of water-soluble calcium hydroxycitrate in Garcinia atroviridis on the short-term treatment of obese women in Thailand. Asia Pacific Journal Clinical Nutrition, 16(1):74-86, 2007.
SALGADO, P. et al. Sunflower protein films incorporated with clove essential oil have potential application for the preservation of fish patties. Food Hydrocolloids, 33(1):7484, 2013.

SÁNCHEZ-GONZÁLEZ, L. et al. Physical properties of edible chitosan films containing bergamot essential oil and their inhibitory action on Penicillium italicum. Carbohydrate Polymers, 82(2):277-283, 2010.

SEYDIM, A.; SARIKUS, G. Antimicrobial activity of whey protein based edible films incorporated with oregano, rosemary and garlic essential oils. Food Research International, 39(5):639-644, 2006.

SHAABAN, H. A. et al. Antimicrobial activity of edible methyl cellulose films enriched with essential oils against three common foodborne pathogens. World Applied Sciences Journal, 32:2092-2101, 2014.

SIRIPATRAWAN, U.; HARTE, B. Physical properties and antioxidant activity of an active film from chitosan incorporated with green tea extract. Food Hydrocolloids, 24(8):770-775, 2010.

TOLDRA, F. et al. Handbook of Fermented Meat and Poultry. 2nd Edition. New Jersey: John Wiley and Sons, $276 p, 2014$.

TOMAC, A.; YEANNES, M. I. Gamma radiation effect on quality changes in vacuum-packed squid (Illex argentines) mantle rings during refrigerated $\left(4-5^{\circ} \mathrm{C}\right)$ storage. International Journal of Food Science and Technology, 47(7):15501557, 2012.

TRINETTA, V. Definition and function of food packaging. Reference Module in Food Science, 1-2, 2016.

ZAILUDDIN, N.; HUSSEINSYAH, S. Tensile properties and morphology of oil palm empty fruit bunch regenerated cellulose biocomposite films. Procedia Chemistry, 19:366372, 2016. 